\title{
Accounting
}

\section{The role of internal factors in determining the firm value in Indonesia}

\author{
Etty Puji Lestari ${ }^{a^{*}}$, Diah Astuti ${ }^{a}$ and M. Abdul Basir ${ }^{b}$
}

${ }^{a}$ Department of Economics, Faculty of Economics, Universitas Terbuka, Indonesia

${ }^{b}$ Master of Management Program, Universitas Terbuka, Indonesia

\section{CH R O N I C L E A B S T R A C T}

\section{Article history:}

Received May 152020

Received in revised format May

162020

Accepted June 292020

Available online

June 292020

Keywords:

Firm value

Leverage

Profitability

Company size
There are pros and cons to the internal factors of the firm value. Some internal factors that play a role in firm value are company size, leverage, and profitability. The purpose of this study is to analyze the internal factors that influence the firm value. The research sample is all companies listed on the Indonesia Stock Exchange in 2012-2017. The dependent variable in this study is the firm value, while the independent variables are firm size, leverage, and profitability. The method used is the data panel. The results show that leverage had a negative and significant effect on firm value. In contrast, profitability and company size had a positive but insignificant effect on firm value. The results are in line with the allegation that the larger the company's size, the higher the investor's confidence in the company's ability to provide a return on investment. This evidence is in line with the allegations in the hypothesis that company size has a positive effect on its value.

\section{Introduction}

In general, the purpose of establishing a company is to maximize the wealth of shareholders. These objectives can be achieved by optimizing the firm value. Especially for companies that have to go public, the company should maximize the value of the stock price to accomplish that goal (Aggarwal \& Padhan, 2017; Nguyen et al., 2019; Ibrahim, 2020). The value of share price can be interpreted as the market value of the company that can prosper the shareholders; therefore, the increase of the share price of a company increases the welfare of its shareholders (Hasnawati, 2005; Yuniningsih et al., 2019; Ibrahim, 2020). A high value of a company can ultimately increase the credibility for the investors since the they assess the company based on share prices. Recently, Indonesia, one of the countries in the Southeast Asian region, tries to build the national economy, and it is indicated by a large number of companies that are listed actively on the share exchange. The development of the stock exchange can be seen from the increasing number of companies offering initial and secondary shares, by 2017 reaching 567 companies (IDX, 2018). The growing number of companies listed on the stock exchange is supported by several aspects, and one of them is the active role of the government, which facilitates investment. The easy access to listing and the increasing number of companies that play actively on the share market will open a great opportunity for the government of Indonesia to develop its economy.

* Corresponding author.

E-mail address: ettypl@ecampus.ut.ac.id (E. P. Lestari) 
In measuring firm value, several measuring tools can be used. One of them used by share analysts is the price to book value (PBV). PBV can be interpreted as a comparison between the share price and the book value per share. The higher the PBV value of a company means the higher level of return of shares received by shareholders, and the ultimate goal is increasing the shareholder wealth. The stock price is a factor that can represent the value of the company. There are three types of elements representing the firm value: internal, external, and technical. Internal and external factors are the most fundamental factor as it relates to the decision making policy by investors in the stock market. While technical factors have technical and psychological properties include stock transaction volumes, stock value, and stock price volatility. In this study, the researchers focus on internal factors because there have been many previous studies examining the effect of internal factors on share values. There are several aspects of internal factors that influence firm value; some of them are company size, leverage (source of funding), and profitability. In this study, the size of a company's profitability is measured by establishing the return rate of all assets owned by the company (Return on Asset/ROA).

\section{Table 1}

Research Gap

\begin{tabular}{ll}
\hline \multicolumn{1}{c}{ Research result } & Researcher \\
\hline Company size had a positive influence on firm value & (Gill \& Obradovich, 2012) \\
Company size had a negative influence on firm value & (Naceur \& Goaied, 2002) \\
Leverage had a positive influence on firm value & (Cheng \& Tzeng, 2011), (Hermuningsih, 2014) \\
Leverage had a negative influence on firm value & (Naceur \& Goaied, 2002),(Yuyetta, 2009), (Kodongo et al., 2015) \\
ROA had a positive influence on firm value & (Hermuningsih, 2014) \\
ROA had a negative influence on firm value & (Aldiena \& Al Hakim, 2019) \\
\hline Source: Compiled by the authors based on research results
\end{tabular}

Source: Compiled by the authors based on research results

The result from the previous researches was various (see Table 1). Some researchers found that the company's size was positively influential towards its value (e.g., Gill \& Obradovich, 2012). In contrast, Naceur \& Goaied, (2002) study stated that the company's size was negatively influential on its value. The same finding is also found in the leverage variable. Leverage had a positive influence on PBV (Cheng \& Tzeng, 2011, Hermuningsih, 2014), but this results in contrast to the studies conducted by Naceur \& Goaied, (2002), Yuyetta, (2009), (Kodongo et al., (2015). ROA is a proxy for company profitability (Ang, 1997). ROA had a positive influence on firm value (Hermuningsih, 2014), but Aldiena and Al Hakim, (2019) found that ROA has the opposite impact. Based on the results of various previous studies, this study will examine the influence of internal factors, namely company size, leverage, and profitability on the firm value listed on the Indonesian Stock Exchange.

\section{Literature Review}

\subsection{The Firm Value Concept}

The firm value is the investor's perception regarding the level of success of a company. The success of this company has a very close relationship to share prices (Sujoko \& Soebiantoro, 2017). The increasing share price reflects the firm value, which is also increasing, and the increase in share prices can also boost market confidence both on the company's performance at present or in the incoming future. The share price, which is generally used as a reference or basis for determining firm value is the closing price, also known as the price at trading in share. The firm value can be measured by PBV. PBV is a comparison between the share price and the book value of the share market. PBV that has a high value can increase market confidence in the company's forecasting in the future and one of the reasons shareholders have a high level of welfare. Besides, the PBV can be used to determine whether shares traded by companies are shares that are undervalued (below) or overvalued (above) shares book (Fakhrudin \& Hardianto, 2001).

\subsection{Company Size in Theoretical Perspective}

The company size is one of the variables that can determine the value of the company. The size of the company can explain the number of total assets owned by the company. When the size of a large company, the assets owned by the company are also more significant, and the funds needed by the company is operating the jug increasingly more significant, (Aggarwal \& Padhan, 2017; Gill \& Obradovich, 2012). Large or small size of a company can impact the decision on the type of funding to be taken by the management of the company. Company size can be indicated by the total assets owned by the company. Large companies can indicate that the company is experiencing growth so that it can ultimately increase the company's value. In contrast, the value of the enlarged company can also be seen from the total assets owned by the company. From the above proposition, the researchers draw the first hypothesis.

$\mathrm{H}_{1}$ : Company size has a positive influence on firm value. 


\subsection{Leverage Company}

Leverage is a decision taken by a company in connection with a funding policy. Companies that in their operational activities use debt have obligations towards the interest and principal loan obligations. The use of funding that comes from external funding sources has a high risk if it is unpaid, so the use of funds derived from debt is taken into account with the company's ability to obtain the level of profit (Prasetyorini, 2013). The use of greater leverage can increase the amount of burden and risk that must be borne by the company. Thus, it can be said that leverage has a negative influence on the value of the company. From the above proposition, the second hypothesis can be derived.

$\mathrm{H}_{2}$ : Leverage has a positive influence on firm value.

\subsection{Company Profitability}

Reflections on companies in the future can be seen from the level of profitability obtained by the company. Profitability can also describe the level of effectiveness of management in managing a company. The level of profitability of the company can be seen through various indicators such as operating profit, net income, the rate of return on investment or assets, and the rate of return on equity for owners. According to Ang (1997), profitability ratios can be used to measure the level of success of a company in obtaining profits. The greater the company's profitability level, the higher the value of the company. Various kinds of proxies can be used to measure the level of profitability of a company, namely, Gross Profit Margin, Net Profit Margin, Return on Investment (ROI), Return on Equity (ROE), and ROA. In this study, the proxy used to measure profitability is ROA because ROA can describe how much the rate of return of all assets owned by the company. From the above proposition, the researchers draw the third hypothesis.

\section{$\mathrm{H}_{3}$ : Profitability a positive influence on firm value.}

\section{Research methods}

This study uses data in the form of secondary data, and the data was obtained from sources that published information about the company's financial statements, namely the Indonesia Stock Exchange through www.idx.org. The study population is all companies listed on the Indonesian stock exchange during 2012-2017. The sampling technique used was purposive. The dependent variable in this study is firm value, and the independent variables are company size, leverage, and profitability. The firm value in this study is the share price reflected through PBV. The size of the company is the total assets owned by the company. Leverage is the number of debt funds from external sources. Leverage a proxy of the debt-equity ratio (DER). Profitability is the level of profit earned by the company, a proxy of ROA.

\subsection{Panel Data Regression}

Panel data is data that consists of a combination of data in the form of time series data and cross-section data. Using data in panel data form has several advantages: first, the panel data can provide more data, which in turn can show more degrees of freedom (degree of freedom) as well. Second, the panel data, which is a combination of time series data and cross-section data, can solve problems when omitted variables occur (Widarjono, 2009). In the panel data regression analysis, the findings of the different models used, such as one-way or two-way models, can be formed by focusing more on error-term. If the regression model used is a one-way error, the component contained in it is only one effect that is in the form of personal effects or time effects. However, if the regression model used is a two-way effect, the components of the model will have two error terms in the form of personal effects and time effects (Hsiao, 1986). In determining the panel data regression model, which is a combination of data time series and cross-section, data can be collected in three different ways of estimating parameters. The three types of methods include the common effect model (CEM), the fixed-effect model (FEM), and the random effect model (REM) (Gujarati \& Porter, 2009). The CEM regression in some other literature is referred to as pooled ordinary least square (POLS), which bases its analysis with the least-squares method (OLS). In this CEM model, it is simply a combination of all data (pooled) in the form of time series or cross-sections, which are further estimated using the OLS method. The fixed effect method is a regression of panel data using dummy variables. In this method, the value of the slope coefficient is constant (fixed), but the intercept varies between each individual. While for the random effect method, the value of all personal effects is random for all cross-section units. To determine the best type of model, we use the Chow and Hausman test.

\section{Research Model}

The model used in this study is:

$$
\text { FIRM }_{i j t}=\alpha+\beta_{1} \text { SIZE }_{i t}+\beta_{2} L E V_{i t}+\beta_{3} \text { PROFIT }_{i t}+\varepsilon
$$

where:

$$
\begin{array}{llll}
\mathrm{Y}=\text { Firm value } & \begin{array}{l}
\alpha=\text { regression } \\
\text { parameter }
\end{array} & \begin{array}{l}
\beta=\text { coefficient of } \\
\text { determination }
\end{array} & \begin{array}{l}
\mathrm{X}_{1}=\text { size } \\
\text { company }
\end{array}
\end{array} \quad \begin{aligned}
& \mathrm{X}_{2}=\text { leverage } \\
& \mathrm{X}_{3}=\text { Profit }
\end{aligned} \quad \varepsilon=\text { residual }
$$




\section{Results and Discussion}

From the results of the descriptive statistics table above, it can be seen that firm value, company size, Leverage, and profitability have normal data distribution forms. This can be seen from the Jarque Bera probability value ( $p$-value) of all variables, and the value is lower than the minimum limit $(0.05)$. Thus, it can be said that the data has a normal distribution pattern.

\subsection{Unit Root Test}

The unit root test results found that all variables are stationary. From Table 2, it can be seen that each variable used in the study, such as Size and DER in the level test stage. This can be seen from the $p$-value of all variables, and the value is 0.00 . While for the PBV and ROA variables in the unit root test in the level of the test stage is not stationary because the value of the $p$-value is greater than 0,05 .

\section{Table 2}

Unit Root Test Results

\begin{tabular}{|c|c|c|c|c|c|c|}
\hline & \multicolumn{4}{|c|}{ Zero Order (I (0) } & \multicolumn{2}{|c|}{ First Difference (I (1) } \\
\hline & T statistic & $\mathrm{P}$ value & Information & T statistic & $\mathrm{P}$ value & Information \\
\hline Firm & 90.1848 & 0.4747 & Not stationary & 231,983 & 0.0000 & Stationary \\
\hline Size & 146,994 & 0.0001 & Stationary & 216,287 & 0.0000 & Stationary \\
\hline Leverage & 128,640 & 0.0047 & Stationary & 146,420 & 0.0002 & Stationary \\
\hline Profit & 104,368 & 0.1428 & Not stationary & 150,048 & 0.0001 & Stationary \\
\hline
\end{tabular}

However, in the level testing stage 1 , the $p$-value is smaller than 0,05 so that the PBV and ROA variables are stationary. This shows that the PBV and ROA variables are not stationary at the level stage test, but stationary at the level test stage 1.

\subsection{Regression Model Estimation}

In the regression model in the form of panel data, the estimation of the parameters used can be done by using three types of methods. The method consists of CEM, FEM, and random effects. The comparison of the results of those variables is presented in the following table.

Table 3

Summary Table of Regression

\begin{tabular}{|c|c|c|c|}
\hline Variable & Common Effect & Fixed Effect & Random Effect \\
\hline \multirow[t]{3}{*}{ Cons } & $-29,148380$ & 3.184950 & $-43,37923$ \\
\hline & $(-1,499794)$ & $(0.042058)$ & $(-1.832037)$ \\
\hline & Prob $=0.1351$ & Prob $=0.9665$ & Prob $=0.0683$ \\
\hline \multirow[t]{3}{*}{ Size } & 2.148380 & 0.967615 & 3,098280 \\
\hline & $(1.8870084)$ & $(0.225166)$ & $(2,285931)$ \\
\hline & Prob $=0.0628$ & Prob $=0.8221$ & Prob $=0.0232$ \\
\hline \multirow[t]{3}{*}{ Leverage } & -2.441076 & $-7,397159$ & $-3,754900$ \\
\hline & $(-4,513127)$ & $(-8,941909)$ & $(-6,577262)$ \\
\hline & Prob $=0,000$ & Prob $=0.0000$ & Prob $=0.0000$ \\
\hline \multirow[t]{6}{*}{ Profit } & .227801 & $-0,082175$ & 0.188007 \\
\hline & $(1.582861)$ & $(-0,227167)$ & $(1.125270)$ \\
\hline & Prob $=0.1149$ & Prob $=0.8206$ & Prob $=0.2617$ \\
\hline & $\mathrm{R}^{2}=0.095668$ & $\mathrm{R}^{2}=0.500705$ & $\mathrm{R}^{2}=0.148918$ \\
\hline & $\mathrm{F}_{\text {stat }}=7.793130$ & $\mathrm{~F}_{\text {stat }}=3.776590$ & $\mathrm{~F}_{\text {stat }}=12.88978$ \\
\hline & $\operatorname{Prob}\left(\mathrm{F}_{\text {stat }}=0.000057\right)$ & Prob $\left(F_{\text {stat }}=0.0000\right)$ & $\operatorname{Prob}\left(\mathrm{F}_{\text {stat }}=0.0000\right)$ \\
\hline
\end{tabular}

Source: appendix of data tabulation

Column 1 is the independent variables used in regression modeling. Column 2 is the parameter regression using the CEM estimation, while column 3 is the parameter regression using FEM estimation and column 4 is a parameter regression using a REM estimation. Figures in each successive row are the coefficient of each variable; the numbers in parentheses are t-statistics while the lowest is the probability value ( $p$-value), signification level of each variable. Based on the table, the parameters for the panel data regression model with the CEM are:

FIRM $=-29,148380+2,148380$ LSize $-2,441076$ LEV $+0,227801$ PROFIT

$\mathrm{R}^{2}=0.095668 \mathrm{~F}_{\text {stat }}=7.793130$ Prob $\left(\mathrm{F}_{\text {stat }}=0,000057\right)$

While for the panel data regression model equation using the FEM method without a dummy variable are as follows: 
FIRM $=3.184950+0.967615$ LSize $-7,397159$ LEV $-0,082175$ PROFIT

$\mathrm{R}^{2}=0.500705 \mathrm{~F}_{\text {stat }}=3.776590$ Prob $\left(\mathrm{F}_{\text {stat }}=0,0000\right)$

As for the panel data regression, the model equation is using the REM method:

FIRM $=-43,37923+3.098280$ LSize -3.754900 LEV +.188007 PROFIT

$\mathrm{R}^{2}=0.148918 \mathrm{~F}_{\text {stat }}=12,88978 \operatorname{Prob}\left(\mathrm{F}_{\text {stat }}=0.0000\right)$

According to the Chow test results, it can be seen that the resulting p-value is 0.000 . This indicates that the model with fixed effects is better than the common effect model. In the Chow trial phase, it can be seen that the fixed effect model is better than the common effect model. Then it is necessary to do another test for the selection of models between fixed effects and random effects.

\section{Table 4}

Chow and Hausman Test

\begin{tabular}{clcc}
\hline & Effects Test & Statistics & Prob. \\
\hline Chow test & Cross-section F & 3,263302 & $(44,177)$ \\
& Chi-square cross-section & 0.0000 & $133,649,686$ \\
Hausman Test & Random cross section & 0.0000 & 38.259341 \\
\hline
\end{tabular}

According to the Hausman test results in Table 4, it can be seen that the resulting $p$-value is 0,000 . This indicates that the model with the fixed effect is better than the random effect model because, in the Chow trial phase, the fixed-effect model is better than the random effect model.

\section{Table 5}

Research Hypothesis Testing

\begin{tabular}{|c|c|c|c|c|}
\hline Variable & Coefficient & Std. Error & t-Statistics & Prob. \\
\hline SIZE & 0.967615 & 4,297348 & 0.225166 & 0.8221 \\
\hline LEVERAGE & -7.397159 & 0.827246 & -8.941909 & 0.0000 \\
\hline PROFIT & -0.082175 & 0.361737 & -0.227167 & 0.8206 \\
\hline R-squared & 0.500705 & Mean dependent var & & 4.408578 \\
\hline Adjusted R-squared & 0.368124 & SD dependent var & & 21.83000 \\
\hline SE of regression & 17.35281 & Akaike info criterion & & 8.732102 \\
\hline Sum squared resid & 53298.25 & Schwarz criterion & & 9,460870 \\
\hline Log-likelihood & -934.3615 & Hannan-Quinn criteria. & & 9.026236 \\
\hline F-statistics & 3.776590 & Durbin-Watson stat & & 1.991119 \\
\hline Prob (F-statistic) & 0.000000 & & & \\
\hline
\end{tabular}

From the results of the regression model in Table 5, it can be seen that the calculated F value is 3.776590 , with a probability value or $p$-value calculated of 0,00000 . Thus, the value of the $p$-value is smaller than the value of the level of significance testing that has been set equal to 0,05 . This shows that the dependent variables jointly have an influence and are not significant to the dependent variable. From Table 5, it can be seen that the size regression coefficient is 0.967615 . While for the $p$-value of 0,8221 . This shows that company size has a positive and significant effect on firm value. This means that the larger the size of the company will increase the firm value. This is in line with the theory that the larger the size of a company, the easier to obtain a source of funding, which then can be utilized by management to increase the value of the company. These results are consistent with the notion that the bigger the size of the company, the higher credibility of investors to the company's ability to provide the return on investment. This evidence confirms the line with the allegations in the hypothesis that company size has a positive effect on firm value. The positive influence indicates that large companies tend to provide greater operating results so that they have more exceptional ability to provide a more profitable investment return than the company. This finding supports the study conducted by (Gill \& Obradovich, 2012). The coefficient value of leverage regression is -7,397159, and the $p$-value is 0,000 . This result shows that leverage has a negative and significant effect on firm value. Leverage numbers show negative and significant so that leverage can reduce firm value. In other words, when leverage experiences an increase, the value of the company decreases. Negative leverage is caused by the average value of leverage every year is quite high, and experience rise and falls. A good ratio occurs when debt and capital are balanced. This shows that companies still use the composition of debt more than their money, and as a result, the value of the company is reduced. This study supports the findings of (Kodongo et al., 2015; Naceur \& Goaied, 2002; Yuyetta, 2009). The coefficient value of profit is $-0,0821$, and the $p$-value is 0.8206 . This shows that profit has a negative but insignificant effect on the value of the company. In this condition, the company faces low profitability; to maintain reputation, it pays large dividends. By maintaining dividends, the investor estimates high profitability even though, in reality, they will not get high profitability. The behavior of dividend payments is also supported by preferences to get large dividends. On the contrary, companies with high profitability tend to pay low dividends. It happens because the company will allocate profits to retain earnings for future expansion purposes. The results of this study are following (Jensen et al., 1992). 


\section{Conclusion}

From the results of the study, only company size variables are following the theory. This result is in line with the allegation that the larger the company's size, the higher the investor's confidence in the company's ability to provide a return on investment. This evidence confirms the line with the allegations in the hypothesis that company size has a positive effect on its value. While ROA and leverage variables have a negative relationship, this condition occurs because the average amount of DER is quite high, and experience rise and fall each year. This shows that companies still use the composition of debt more than their capital. As a result, the value of the company decreased.

\section{References}

Aggarwal, D., \& Padhan, P. C. (2017). Impact of Capital Structure on Firm Value: Evidence from Indian Hospitality Industry. Theoretical Economics Letters, 7(4), 982-1000. https://doi.org/10.4236/tel.2017.74067

Aldiena, E., \& Al Hakim, M. H. (2019). The Impact of Companies' Internal Factors On The Performance of Their Stock Returns. Journal of Islamic Economic Laws, 2(1), 120-149. https://doi.org/10.23917/jisel.v2i1.7708

Ang, R. (1997). Buku Pintar Pasar Modal Indonesia. Jakarta: Mediasoft Indonesia

Cheng, M.-C., \& Tzeng, Z.-C. (2011). The Effect of Leverage on Firm Value and How The Firm Financial Quality Influence on This Effect. World Journal of Management, 3(2), 30-53.

Fakhruddin, S., \& Hardianto. (2001). Perangkat dan Model Analisis Investasi di Pasar Modal. Jakarta: Alex Media Komputindo.

Gill, A., \& Obradovich, J. (2012). The Impact of Corporate Governance and Financial Leverage on The Value of American Firms. International Research Journal of Finance and Economics, 91(91), 46-56.

Hasnawati, S. (2005). Dampak Set Peluang Investasi Terhadap Nilai Perusahaan Publik di Bursa Efek Jakarta. JAAI, 9(2), 117126.

Hermuningsih, S. (2014). Profitability, Growth Opportunity, Capital Structure and the Firm Value. Buletin Ekonomi Moneter Dan Perbankan, 16(2), 115-136. https://doi.org/10.21098/bemp.v16i2.440

Gujarati, D. N., \& Porter, D. C. (2012). Dasar-Dasar Ekonometrika. Jakarta: Salemba Empat.

Hsiao, C. 1986. Analysis of Panel Data. New York: Cambridge University Press.

Ibrahim, U. A. (2020). Effect of Financial Leverage on Firm Value: Evidence From Selected Firms Quoted on the Nigerian Stock Exchange. European Journal of Business and Management, 12(3), 124-135. https://doi.org/10.7176/ejbm/12-3-16

Jensen, G. R., Soelberg, D. P., \& Zorn, T. S. (1992). Simultaneous Determination of Insider Ownership, Debt , and Dividend Policies. Journal of Financial and Quantitative Analysis, 27(2), 247-263.

Kodongo, O., Mokoaleli-Mokoteli, T., \& Maina, L. N. (2015). Capital Structure, Profitability and Firm Value: Panel Evidence of Listed Firms in Kenya. African Finance Journal, 17(1), 1-20. https://doi.org/10.2139/ssrn.2465422

Naceur, S. Ben, \& Goaied, M. (2002). The Relationship Between Dividend Policy, Financial Structure, Profitability and Firm Value. Applied Financial Economics, 12(12), 843-849. https://doi.org/10.1080/09603100110049457

Nguyen, V. C., Nguyen, T. N. L., Tran, T. T. P., \& Nghiem, T. T. (2019). The Impact of Financial Leverage on The Profitability of Real Estate Companies: A study from Vietnam Stock Exchange. Management Science Letters, 9(Spceial Issue 13), 23152326. https://doi.org/10.5267/j.msl.2019.7.023

Prasetyorini, B. F. (2013). Pengaruh Ukuran Perusahaan, Leverage, Price Earning Ratio dan Profitabilitas terhadap Nilai Perusahaan. Jurnal Ilmu Manajemen (JIM), 1(1).

Sujoko, \& Soebiantoro, U. (2017). Pengaruh Struktur Kepemilikan, Strategi Diversifikasi, Leverage, Faktor Intern dan Faktor Ekstern Terhadap Nilai Perusahaan (Studi Empirik Pada Perusahaan Manufaktur dan Non Manufaktur di Bursa Efek Jakarta). EKUITAS (Jurnal Ekonomi Dan Keuangan), 11(2), 236. https://doi.org/10.24034/j25485024.y2007.v11.i2.2236

Widarjono, A. (2009). Ekonometrika Pengantar dan Aplikasinya. Yogyakarta: Ekonisia.

Yuniningsih, Y., Pertiwi, T. K., \& Purwanto, E. (2019). Fundamental Factor of Financial Management in Determining Company Values. Management Science Letters, 9(2), 205-216. https://doi.org/10.5267/j.msl.2018.12.002

Yuyetta, E. N. A. (2009). Pengaruh Leverage Terhadap Nilai Perusahaan Pada Masa Krisis : Pengujian Empiris di Indonesia. Journal of Accounting and Auditing, 5(2), 148-163-163.

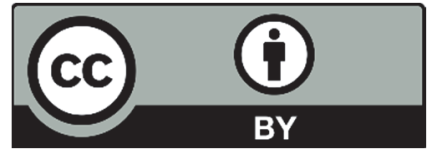

(C) 2020 by the authors; licensee Growing Science, Canada. This is an open access article distributed under the terms and conditions of the Creative Commons Attribution (CC-BY) license (http://creativecommons.org/licenses/by/4.0/). 